\title{
Analisis Deskriptif Pengguna Go-Pay di Surabaya
}

\author{
Huwaydi, Y., Hakim, M, S., dan Persada, S. F. \\ Departemen Manajemen Bisnis, Fakultas Bisnis dan Manajemen Teknologi, \\ Institut Teknologi Sepuluh Nopember (ITS) \\ e-mail: saiful.hakim5@yahoo.com
}

\begin{abstract}
Abstrak - Financial technology atau fintech merupakan inovasi dibidang finansial yang bertujuan untuk memudahkan pengguna dalam melakukan kegiatan finansial dan memudahkan perusahaan dalam memberikan pelayanan keuangannya. GO-PAY adalah salah satu fintech di Indonesia yang merupakan layanan mobile payment yang terdapat pada platform GO-JEK. GO-PAY disediakan untuk memberikan kemudahan dan kenyamanan bagi proses transaksi yang dilakukan dalam GO-JEK. Penelitian ini dilakukan untuk menganalisa penggunaan dari layanan GO-PAY itu sendiri. Didapat sebanyak 646 data yang dapat diolah pada penelitian ini. Dari hasil tersebut ditemukan beberapa demografi yang kemudian dianalisis. Salah satunya adalah banyaknya pengguna GO-PAY yang mempunyai jenis kelamin perempuan dan layanan yang sering menggunakan GO-PAY sebagai media transaksinya adalah GO-FOOD.
\end{abstract}

Kata Kunci-Demografi, GO-PAY, Mobile Payment, Usage.

\section{PENDAHULUAN}

I NDONESIA sekarang sedang memasuki era globalisasi dan digitalisasi. Kegiatan yang dilakukan masyarakat Indonesia tidak jauh dari unsur teknologi dan unsur digital. Lajunya perpindahan informasi dan data yang sangat cepat, hingga perilaku dari masyarakat perlahan mulai berubah seiring dengan perkembangan teknologi. Kegiatan mulai dari keseharian, pendidikan, hingga bisnis kini berubah. Tranksaksi global pun berjalan seakan tidak ada sekat perbedaan negara dan geografi. Terdapat banyak platform bisnis yang menjadikan jaringan sebagai core bisnisnya, seperti Alibaba, Amazon, dan lain sebagainya.

Perkembangan e-commerce di Indonesia pun terbilang cukup cepat, meskipun baru memasuki tahap perkenalan. Berbeda dengan Tiongkok, Indonesia masih tertinggal jauh jika dilihat dari perkembangan e-commerce. Namun tidak menutup kemungkinan bahwa Indonesia akan menjadi pemain ekonomi digital terbesar di Asia Tenggara. Hal ini didukung oleh bentuk negara Indonesia yang merupakan negara kepulauan, e-commerce sangat cocok bagi Indonesia. Selain itu, demografi di Indonesia yang saat ini mengalami peningkatan kelas menengah akan menjadi salah satu faktor e-commerce terus tumbuh. Kelas menengah dengan daya konsumsi yang tinggi akan meningkatkan performa $e$ commerce di Indonesia. Kepala Bappenas, Bambang Brodjonegoro memprediksi jumlah masyarkat kelas menengah akan terus meningkat. Kini jumlah kelas menengah berjumlah 40 juta jiwa, dan akan naik 5 kali lipat di tahun 2020 menurut Kepala Bappenas dikutip dari Media Indonesia.

Kemudahan transaksi dari e-commerce sendiri merupakan salah satu daya tarik mengapa masyarakat lebih memilih untuk berbelanja online dari pada offline [1].

Kemudahan dalam mobile payment sendiri akan terasa manfaatnya bagi penduduk yang angka transaksi online-nya terus meningkat. Menurut penelitian yang dilakukan oleh Bothun [2], terdapat beberapa keuntungan yang membuat masyarakat memilih untuk menggunakan mobile payment. Keuntungan yang pertama adalah dapat lebih berhemat. Perusahaan biasanya memberikan promosi terhadap pengguna dompet digital mereka dengan coupon atau diskon dari jasa yang mereka tawarkan.

Responden dari penelitian Bothun [2] beranggapan dengan banyaknya diskon dapat menghemat pengeluaran mereka. Keuntungan berikutnya adalah kemudahan dalam transaksi dan keseharian. User tidak perlu membawa dompet untuk melakukan transaksi, cukup dengan smartphone dan jaringan internet mereka bisa bertransaksi, maka dari itu adanya mobile payment ini dapat mempermudah proses transaksi. Bagaimanapun kemudahan dalam transaksi merupakan daya tarik tersendiri bagi user atau pelanggan [3].

\section{TINJAUAN PUSTAKA}

\section{A. Perilaku Konsumen}

Konsumen adalah seseorang yang menggunakan atau memakai produk atau jasa yang disediakan [4]. Konsumen adalah individu yang membeli produk atau jasa untuk dirinya. Konsumen adalah seseorang pengambil keputusan yang mana mempunyai kuasa penuh atas keputusan membeli atau tidak membeli barang atau jasa. Menurut Kotler [5] konsumen adalah individu yang membeli dari orang lain.

Jadi yang disebut konsumen adalah orang yang memegang kendali atas keputusan pada suatu pembelian dan menggunakan produk yang ia beli. Perilaku konsumen adalah serangkaian proses yang dijalani oleh individu dalam mencari, membeli, menggunakan, mengevaluasi dan bertindak pasca penggunaan produk ataupun jasa dalam pemenuhan kebutuhannya [6]. Menurut Kotler [5] perilaku konsumen merupakan studi mengenai seseorang, kelompok atau organisasi memilih, membeli, menggunakan, suatu barang, jasa, atau pengalaman untuk memenuhi kebutuhan dan memuaskan diri mereka. Sedangkan menurut American Marketing Association mendefinisikan perilaku konsumen sebagai sebuah dinamika interaksi antara pengaruh dan kesadaran, lingkungan, perilaku, dimana terjadi pertukaran aspek-aspek oleh manusia [7].

\section{B. GO-PAY}

GO-PAY merupakan metode pembayaran mobile payment yang disediakan oleh perusahaan GO-JEK untuk mempermudah proses transaksi bagi pengguna, driver maupun perusahaan itu sendiri. 
Tabel 1. Deskriptif Demografi Responden

\begin{tabular}{|c|c|c|}
\hline Profil & Frekuensi & Persentase $(\%)$ \\
\hline \multicolumn{3}{|l|}{ Jenis Kelamin } \\
\hline Laki - Laki & 276 & 42,7 \\
\hline Perempuan & 370 & 57,3 \\
\hline \multicolumn{3}{|l|}{ Usia } \\
\hline 7 - 21 Tahun & 509 & 78,8 \\
\hline 22 - 36 Tahun & 137 & 21,2 \\
\hline \multicolumn{3}{|l|}{ Pendidikan Terakhir } \\
\hline SMA/Sederajat & 514 & 79,6 \\
\hline Pascasarjana & 1 & 0,2 \\
\hline Diploma & 33 & 5,1 \\
\hline Sarjana & 95 & 14,7 \\
\hline Lainnya & 3 & 0,5 \\
\hline \multicolumn{3}{|l|}{ Jenis Pekerjaan } \\
\hline PNS & 6 & 0,9 \\
\hline Pelajar/Mahasiswa & 586 & 90,7 \\
\hline Pegawai Swasta & 25 & 3,9 \\
\hline Lainnya & 18 & 2,8 \\
\hline Wiraswasta & 11 & 1,7 \\
\hline \multicolumn{3}{|l|}{ Pemasukan dalam Sebulan } \\
\hline$<=\operatorname{Rp} 1.000 .000$ & 267 & 41,3 \\
\hline Rp 1.000.001 - Rp 3.000 .000 & 320 & 49,5 \\
\hline Rp 3.000.001 - Rp 5.000.000 & 43 & 6,7 \\
\hline Rp 5.000.001 - Rp 7.000.000 & 8 & 1,2 \\
\hline$>\mathrm{Rp} 7.000 .000$ & 8 & 1,2 \\
\hline \multicolumn{3}{|c|}{ Penggunaan GO-PAY dalam Sebulan } \\
\hline $1 \mathrm{kali}$ & 339 & 52,5 \\
\hline 3 kali & 178 & 27,6 \\
\hline 5 kali & 50 & 7,7 \\
\hline 7 kali & 79 & 12,2 \\
\hline \multicolumn{3}{|l|}{$\begin{array}{l}\text { Layanan GO-JEK dengan } \\
\text { menggunakan GO-PAY }\end{array}$} \\
\hline GO-RIDE & 259 & 40,1 \\
\hline GO-CAR & 45 & 7 \\
\hline GO-FOOD & 333 & 51,5 \\
\hline GO-PULSA & 6 & 0,9 \\
\hline Lainnya & 3 & 0,5 \\
\hline \multicolumn{3}{|l|}{ Nominal Top-up GO-PAY } \\
\hline Rp 50.000 & 256 & 39,6 \\
\hline Rp 50.001 - Rp 100.000 & 332 & 51,4 \\
\hline Rp $100.001-\operatorname{Rp} 200.000$ & 50 & 7,7 \\
\hline Rp $200.001-\operatorname{Rp} 300.000$ & 6 & 0,9 \\
\hline$>\operatorname{Rp} 300.000$ & 2 & 0,3 \\
\hline \multicolumn{3}{|l|}{ Media untuk Top-up GO-PAY } \\
\hline Transfer Bank & 238 & 36,8 \\
\hline Mobile Banking & 206 & 31,9 \\
\hline Internet Banking & 58 & 9 \\
\hline Driver GO-JEK & 128 & 19,8 \\
\hline Via Alfamart & 16 & 2,5 \\
\hline \multicolumn{3}{|l|}{ Saldo GO-PAY Saat Ini } \\
\hline Rp 50.000 & 549 & 85 \\
\hline Rp 50.001 - Rp 100.000 & 78 & 12,1 \\
\hline Rp 100.001 - Rp 200.000 & 15 & 2,3 \\
\hline Rp $200.001-\operatorname{Rp} 300.000$ & 3 & 0,5 \\
\hline > Rp 300.000 & 1 & 0,2 \\
\hline \multicolumn{3}{|c|}{$\begin{array}{l}\text { Promo GO-PAY yang Didapatkan } \\
\text { dalam Sebulan }\end{array}$} \\
\hline- & 157 & 24,3 \\
\hline 1 - 3 kali & 391 & 60,5 \\
\hline 4 - 6 kali & 66 & 10,2 \\
\hline $7-10$ kali & 14 & 2,2 \\
\hline$>10$ kali & 18 & 2,8 \\
\hline \multicolumn{3}{|l|}{ Penggunaan Promo GO-PAY } \\
\hline $\mathrm{Ya}^{\circ}$ & 438 & 67,8 \\
\hline Tidak & 208 & 32,2 \\
\hline JUMLAH RESPONDEN & 646 & 100 \\
\hline
\end{tabular}

\section{METODOLOGI PENELITIAN}

\section{A. Jenis Dato}

Data primer merupakan data yang bersifat original dari peneliti itu sendiri yang berfungsi untuk menyelesaikan masalah penelitian. Data ini akan didapat melalui kuisioner yang akan dijelaskan pada sub bab berikut. Pengumpulan Data

Teknik pengumpulan data yang digunakan pada penelitian ini adalah kuesioner. Penelitian ini menggunakan kuesioner yang digunakan untuk mengumpulkan data terkait variabel-variabel yang nantinya akan diolah. Teknik sampling yang akan digunakan pada penelitian ini adalah nonprobabilitas sampling yang brarti pemilihan responden berdasar pada judgement dari peneliti sendiri [8]. Metode sampling yang digunakan adalah convenience. Metode sampling convenience dipilih atas dasar keterbatasan kemampuan dari peneliti. Kriteria sampel pada penelitian ini adalah pengguna GO-PAY. Data yang diperoleh berjumlah 646 dengan komponen 128 data offline dan 518 data online.

\section{IV.ANALISIS DAN PEMBAHASAN}

\section{A. Analisis Deskriptif}

Analisis deskriptif demografi dan usage dilakukan dalam penelitian ini untuk mengetahui karakteristik demografi responden dan penggunaan layanan $e$-filing pajak orang pribadi. Berikut adalah hasil analisis demografi pengguna $e$ filing pajak orang pribadi di Blitar (Tabel 1).

Mayoritas responden dalam penelitian ini adalah perempuan dengan presentase sebanyak $57,3 \%$. Sedangkan laki-laki hanya sebesar 42,7\% (Gambar 1).

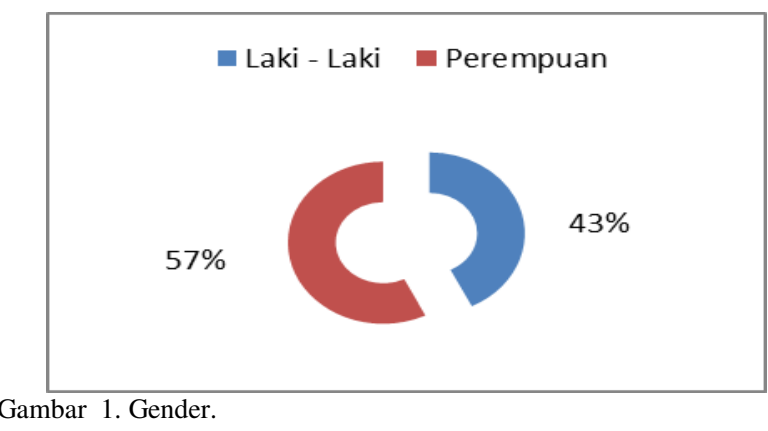

Usia $\leq 21$ tahun mendominasi jumlah responden dengan total presentase $79 \%$. Dua puluh satu persen sisa dari keseluruhan responden merupakan responden dengan rentang usia 22-36 tahun (Gambar 2). Sedangkan opsi jawaban terakhir yaitu usia dengan rentang 37-52 tahun tidak ada. Penulis mengelompokan 3 rentang usia menjadi 3 kelompok yaitu generasi $\mathrm{x}$, generasi $\mathrm{y}$, dan generasi milenial [6].

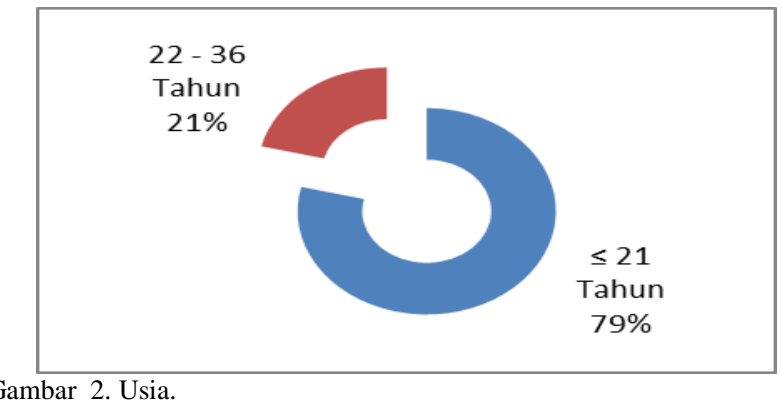

Pendidikan terakhir yang paling banyak adalah SMA dan sederajat. Sebanyak 79,6\% dari total responden mempunyai tingkat pendidikan SMA dan sederajat (Gambar 3). Lalu diikuti oleh sarjana sebanyak 14,7\%, diploma sebanyak $5,1 \%$, lainnya sebanyak $0,5 \%$ dan yang paling sedikit adalah pascasarjana atau magister (S2) dengan angka $0,2 \%$ 


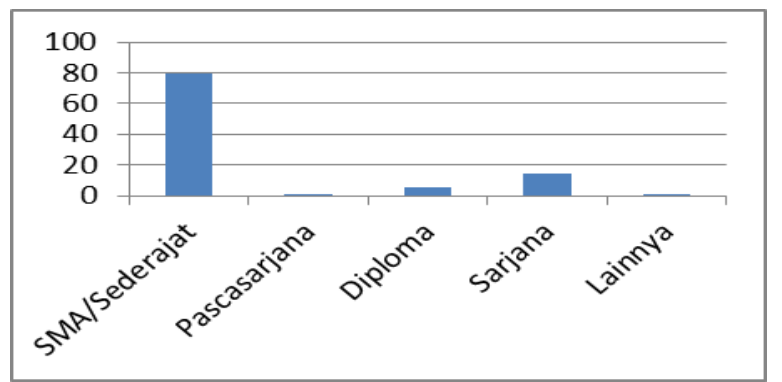

Gambar 3. Pendidikan Terakhir.

Responden dari penelitian ini didominasi oleh kalangan mahasiswa atau pelajar (Gambar 4). Dengan angka mencapai 90,7\% dari total responden. Ini bisa terjadi karena penyebaran offline dilakukan di area kampus, pusat perbelanjaan dan café dimana terdapat banyak sekali pelajar dan mahasiswa yang sedang bermain. Selain itu juga karena penyebaran kuisioner online yang menggunakan relasi penulis sebagai bantuan dalam menyebarkan kuisioner yang rata-rata adalah pelajar juga. Selanjutnya angka sebesar $3,9 \%$ dipegang oleh pegawai swasta, 0,9\% deipegang oleh PNS, 2,8\% pekerjaan lainnya, dan 1,7\% dipegang oleh jenis pekerjaan wiraswasta.

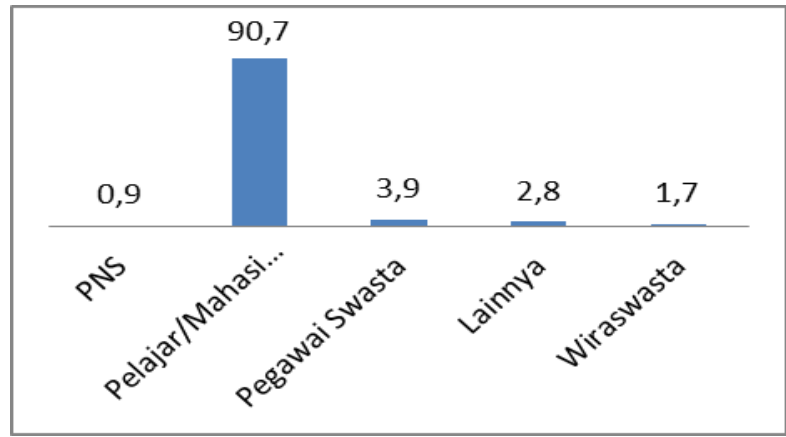

Gambar 4. Pekerjaan.

Terdapat sebanyak 49,5\% dari total responden yang memiliki pemasukan dalam rentang Rp 1.000.001 - Rp 3.000.000 sedangkan responden dengan pemasukan dalam dibawah Rp 1.000.000 menduduki peringkat kedua terbanyak dengan presentase sebesar 41,3\% (Gambar 5). Ini diduga karena sebagian besar responden merupakan pelajar yang masih belum punya pemasukan sendiri. Selanjutnya pemasukan dengan rentang $\mathrm{Rp} 3.000 .001$ - Rp 5.000.000 berada pada angka 6,7\%, Rp 5.000.000 - Rp 7.000.000 sebanyak $1,2 \%$ dan diatas Rp 7.000 .000 sebanyak 1,2\% juga.

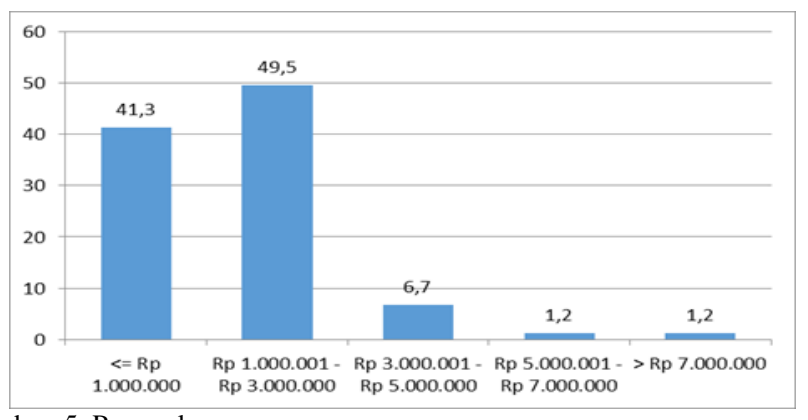

Gambar 5. Pemasukan.

Sebagian besar responden menggunakan jasa GO-PAY sebanyak 1-3 kali dalam sebulan. Penggunaan sebanyak 1-3 kali mendominasi dengan angka sebesar 52\% (Gambar 6). Diikuti dengan frekuensi penggunaan dalam rentang 4-7 kali dalam sebulan dengan angka sebesar $28 \%$ dari total responden. Pengguna GO-PAY lebih dari 10 kali dalam sebulan yaitu dengan angka $12 \%$ mengalahkan tingkat penggunaan dalam rentang 8-10 kali dalam sebulan yang angkanya mencapai $8 \%$.

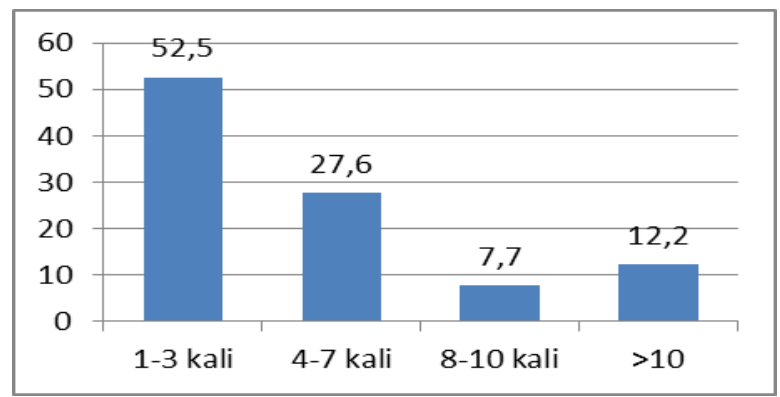

Gambar 6. Frekuensi Penggunaan.

Terdapat 2 layanan yang transaksinya sering menggunakan GO-PAY, yaitu layanan flagship dari GO_JEK sendiri yakni GO-RIDE, lalu layanan yang menawarkan layanan kurir makanan yakni GO-FOOD. Sebanyak $51 \%$ dari total responden menggunakan GO-PAY dalam melakukan transaksi GO-FOOD (Gambar 7). Angka ini mengalahkan GO-RIDE yang menduduki angka sebesar $40 \%$. Kemudian diikuti oleh GO-CAR sebanyak 7\%, GOPULSA sebesar $1 \%$.

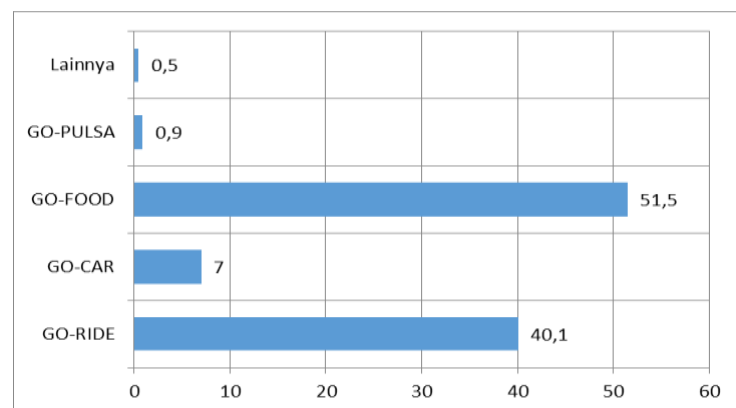

Gambar 7. Layanan GO-JEK.

Orang-orang cenderung melakukan top-up GO-PAY dengan rentang sebesar Rp 50.001 - Rp 100.000. Ini terbukti dengan angka presentase sebesar $51,4 \%$ dari total responden yang mengisi saldo GO-PAY dengan rentang angka Rp 50.001 - Rp 100.000 (Gambar 8). Jumlah nominal pengisian saldo GO-PAY dibawah Rp 50.000 berada pada angka presentase yang cukup besar yaitu $39,6 \%$. Selanjutnya diikuti oleh top-up dengan rentang $\mathrm{Rp} 100.001$ - Rp 200.000 dengan angka sebanyak 7,7\%, Rp 200.001 - Rp 300.000 sebanyak 0,9\% dan terakhir diatas Rp 300.000 yang mencapai angka $0,3 \%$.

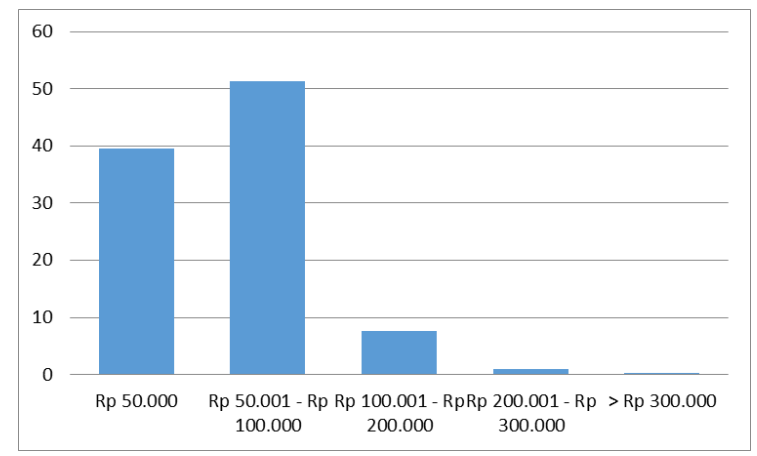

Gambar 8. Nominal Top-Up. 
Pengisian saldo GO-PAY cenderung menggunakan 2 media pengisian, yakni transfer ATM dan transfer via mobile banking. Media yang paling sering digunakan adalah melalui transfer ATM dengan angka presentase sebesar $36,8 \%$ (Gambar 9). Selanjutnya sebanyak 31,9\% top-up melalui mobile banking. Kemudian peringkat 3 terbanyak diduduki oleh media driver itu sendiri yaitu dengan angka sebanyak $19,8 \%$. Lalu kemudian internet banking sebanyak $9 \%$ dan disusul oleh media alfamart sebanyak $2,5 \%$.

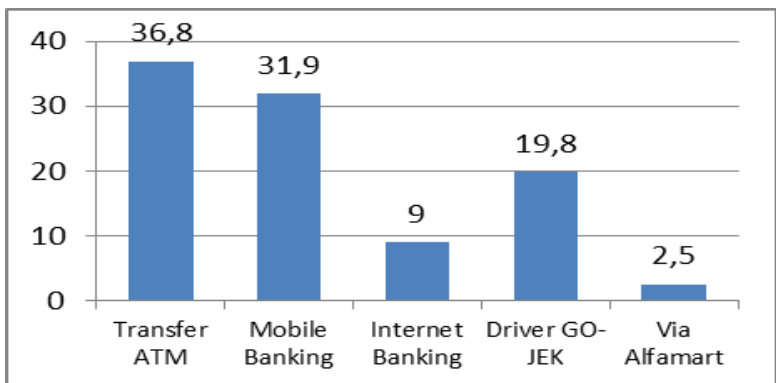

Gambar 9. Media Top-Up.

Sebanyak $85 \%$ dari pengguna GO-PAY memliki sisa saldo dibawah Rp 50.000 (Gambar 10). Lalu diikuti sisa saldo dengan rentang Rp 50.001 - Rp 100.000 dengan presentase sebesar $12,1 \%$. Kemudian diikuti dengan rentang sebesar Rp 100.001 - Rp 200.000 dengan angka presentase 2,3\%, saldo dengan rentang Rp 200.001 - Rp 300.000 sebesar $0,5 \%$ dan terakhir diatas Rp 300.000 sebesar $0,2 \%$.

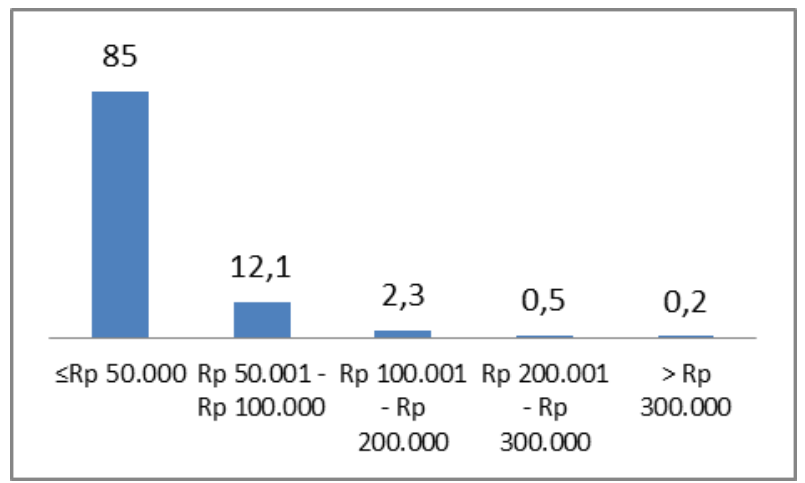

Gambar 10. Nominal Saldo.

Mayoritas pengguna GO-PAY mendapatkan promo sebanyak 1-3 kali dalam sebulan. Ini terbukti dengan capaian angka presentase $60,5 \%$ responden mendapat promo sebanyak 1-3 kali dalam sebulan. $24.3 \%$ responden tidak mendapatkan promo (Gambar 11). Kemudian frekuensi 4-6 kali sebulan mencapai angka sebesar 10,2\%, sebanyak 2,2\% mendapat promo sekitar 7-10 kali dalam sebulan dan terdapat $2,8 \%$ dari responden yang mendapat promo sangat sering diatas 10 kali dalam sebulan.

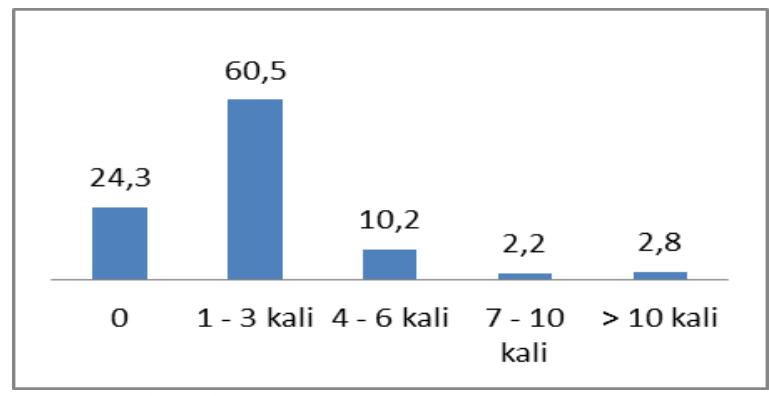

Gambar 11. Frekuensi Promo.
$68 \%$ dari responden pengguna GO-PAY selalu menggunakan promo yang didapat dalam melakukan setiap transaksinya (Gambar 12). Ini jelas karena dengan adanya promo pengguna bisa mengurangi pengeluaran dalam menggunakan semua layanan GO-JEK. Selain itu promo potongan harga yang dikeluarkan oleh pihak GO-JEK ratarata menggunakan GO-PAY sebagai medianya. Namun dibalik itu terdapat $32 \%$ pengguna GO-PAY yang tidak selalu menggunakan promo yang didapat.

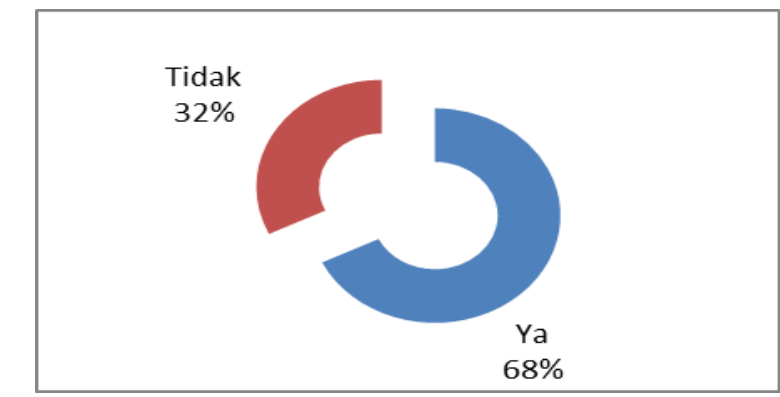

Gambar 12. Penggunaan Promo.

\section{KESIMPULAN}

Analisis deksriptif demografi dalam penelitian ini menunjukkan bahwa pengguna GO-PAY lebih banyak perempuan, hal ini terjadi mungkin karena kebanyakan lakilaki memiliki sendiri kendaraan bermotor. Kelompok usia dalam penelitian ini berada pada generasi Y, karena generasi tersebut sudah biasa akan teknologi. Pendidikan terakhir kebanyakan penggunanya adalah SMA sederajat ini sejalan penemuan berikutnya yang menemukan bahwa pengguna paling banyak dari GO-PAY ini adalah mahasiswa atau pelajar. Pendapatan dalam sebulan juga berada pada rentan Rp 1.000.000,- sampai Rp 3.000.000,-. Ini dikarenakan mahasiswa atau pelajar masih belum memiliki pendapatan sendiri. Penggunaan GO-PAY mayoritas menggunakan GOPAY sebanyak 1-3 kali dalam sebulan dan GO-PAY paling sering digunakan pada layanan GO-FOOD. Jumlah nominal top-up paing banyak ada pada rentan $\mathrm{Rp} 50.000$,- hingga $\mathrm{Rp}$ 100.000 ,- dan media yang paling banyak digunakan oleh user untuk top-up adalah transfer ATM. User biasanya menyisakan saldo pada GO-PAY mereka pada rentan Rp 50.000 kebawah. Sedangkan jika dilihat dari promo, pengguna rata-rata mendapatkan promo dari GO-JEK sebanyak 1-3 kali akan tetapi tidak semua promo yang didapat digunakan.

\section{SARAN}

Saran untuk penelitian selanjutnya dapat meneliti mengenai penggunaan GO-PAY tidak pada segi konsumen atau user saja, melainkan dari dua sisi yaitu konsumen dan driver GO-JEK. Penelitian selanjutnya juga dapat meneliti mengenai bagaimana GO-PAY dalam sudut pandang perusahaan dan bagaimana optimalisasi profit dari uang yang berputar didalam proses perputaran GO-PAY.

\section{DAFTAR PUSTAKA}

J. Nielsen, "Why People Shop on the Web," Nielson Noueman Group, $1999 . \quad$ [Online]. Available: https://www.nngroup.com/articles/why-people-shop-on-the-web/.

[2] D. Bothun, S. Glisson, R. Haas, C. Isaac, and M. Lieberman, "Consumer intelligence series;opening the mobile wallet," PricewaterhouseCoopers LLP, 2013. [Online]. Available: www.pwc.com/sg/en/tice/assets/tmtnews201304/pwc-consumer- 
intelligence-series-mobile-wallet.pdf.

[3] E. Taylor, "Mobile payment technologies in retail: a review of potential benefits and risks," Int. J. Retail. Distrib., 2016.

[4] Fadila and D. Ridho, Perilaku Konsumen. Palembang: Citrabooks, 2013.

[5] P. Kotler and K. L. Keller, Marketing Management. Harlow:
Pearson Education, 2015.

P. Ristiyanti, Perilaku Konsumen. Yogyakarta: Andi Offset, 2004.

[7] J. Peter, Consumer Behavior and Markeitng Strategy. Jakarta: Salemba Empat, 2014. 